\title{
TAPER TANTRUM AND EMERGING EQUITY MARKET SLUMPS
}

Gemma B. Estrada, Donghyun Park, and Arief Ramayandi

\section{NO. 451}

September 2015
ADB ECONOMICS WORKING PAPER SERIES 
ADB Economics Working Paper Series

\section{Taper Tantrum and Emerging Equity Market Slumps}

Gemma B. Estrada, Donghyun Park, and Arief Ramayandi

No. 451 | September 2015
Gemma Estrada (gestrada@adb.org) is Senior Economics Officer, Donghyun Park (dpark@adb.org) is Principal Economist, and Arief Ramayandi (aramayandi@adb.org) is Senior Economist at the Economic Research and Regional Cooperation Department of the Asian Development Bank.

\section{ASIAN DEVELOPMENT BANK}


Asian Development Bank

6 ADB Avenue, Mandaluyong City

1550 Metro Manila, Philippines

www.adb.org

(C) 2015 by Asian Development Bank

September 2015

ISSN 2313-6537 (Print), 2313-6545 (e-ISSN)

Publication Stock No. WPS157625-2

The views expressed in this paper are those of the authors and do not necessarily reflect the views and policies of the Asian Development Bank (ADB) or its Board of Governors or the governments they represent.

ADB does not guarantee the accuracy of the data included in this publication and accepts no responsibility for any consequence of their use.

By making any designation of or reference to a particular territory or geographic area, or by using the term "country" in this document, $A D B$ does not intend to make any judgments as to the legal or other status of any territory or area.

Note: In this publication, "\$” refers to US dollars.

The ADB Economics Working Paper Series is a forum for stimulating discussion and eliciting feedback on ongoing and recently completed research and policy studies undertaken by the Asian Development Bank (ADB) staff, consultants, or resource persons. The series deals with key economic and development problems, particularly those facing the Asia and Pacific region; as well as conceptual, analytical, or methodological issues relating to project/program economic analysis, and statistical data and measurement. The series aims to enhance the knowledge on Asia's development and policy challenges; strengthen analytical rigor and quality of ADB's country partnership strategies, and its subregional and country operations; and improve the quality and availability of statistical data and development indicators for monitoring development effectiveness.

The ADB Economics Working Paper Series is a quick-disseminating, informal publication whose titles could subsequently be revised for publication as articles in professional journals or chapters in books. The series is maintained by the Economic Research and Regional Cooperation Department. 


\section{CONTENTS}

TABLES AND FIGURES $\quad$ iv

ABSTRACT $v$

$\begin{array}{ll}\text { I. INTRODUCTION } & 1\end{array}$

II. LITERATURE REVIEW 2

III. DATA 3

$\begin{array}{llr}\text { IV. } & \text { EMPIRICAL ASSESSMENT } & 7\end{array}$

A. $\quad$ The Baseline Approach 7

B. Does the Exchange Rate Regime Matter? 8

C. Indirect Channel of the Taper Tantrum Effect 10

V. CONCLUSION 11

REFERENCES 


\section{TABLES AND FIGURES}

\section{TABLES}

1. $\quad$ Estimation Results of Equation (1) 8

2 Exchange Rate Regime Classifications 9

3 Relative Real Effective Exchange Rate Volatility against the Sample Average 10

4 Estimation Results of Equation (2) 11

\section{FIGURES}

$1 \quad$ Changes in Equity Indices from the Taper Talk to the Trough 4

2 Autocorrelation and Partial Autocorrelation Functions, Developing Asia 5

3 Autocorrelation and Partial Autocorrelation Functions, Other Developing Economies 6 


\begin{abstract}
In the postglobal financial crisis period, the central banks of the advanced economies pursued unconventional monetary policies, such as the United States (US) Federal Reserve's quantitative easing (QE). Those policies and their unwinding may significantly affect cross-border capital flows and thus destabilize the financial systems of emerging markets. For example, emerging markets experienced substantial financial instability during the taper tantrum triggered by the US Federal Reserve Chairman Ben Bernanke's May 2013 announcement of the potential unwinding of QE. In this paper, we examine the spillovers from the taper tantrum on emerging markets more rigorously by using econometric analysis to empirically assess the effect on equity markets in emerging markets. Our central finding that virtually all emerging market equity markets were affected by the taper tantrum highlights the need for emerging market authorities to remain vigilant about the effects of advanced economy monetary policies on their financial stability.
\end{abstract}

Keywords: capital flows, emerging market, equity market, financial stability, global financial crisis, quantitative easing, taper tantrum

JEL Classification: F32, G15 


\section{INTRODUCTION}

The global financial crisis was a game changer for the global financial environment because it originated in the advanced economies. That crisis was rooted in the United States (US) subprime mortgage market, spread like wildfire across the Atlantic, and came close to paralyzing the financial systems of the US and Europe. Prior to the global crisis, in the postwar era most financial crises had broken out in emerging markets; while those crises often had severe effects on their financial stability and sometimes spilled over into others, they posed little risk to global financial stability. For example, if a crisis erupts in Argentina, the impact can be devastating for the financial markets and the real economy of Argentina, but it has at most a limited impact on the rest of the world. The same cannot be said for crises that originate in large, advanced economies. Due to their sheer size and importance as sources of capital flows, these economies have a disproportionate impact on global financial stability and economic growth, i.e. they are systemically important. For example, many American and European banks and financial institutions withdrew capital from emerging markets in an effort to bolster their balance sheets back home during the global financial crisis.

In a similar vein, the unconventional monetary policies recently pursued by the central banks of the advanced economies to reduce financial instability can have significant spillover effects in the rest of the world. In particular, in response to the financial turmoil and collapsing demand during the global crisis, the US Federal Reserve embarked upon a massive purchase of US government bonds in a desperate bid to stabilize the financial system and support economic growth. The policy, which is known as quantitative easing (QE), consisted of various periods and may have contributed to an expansion of global liquidity, some of which flowed into emerging markets. Park, Ramayandi, and Shin (2014), for example, found that QE, especially during the first period, had a tangible effect on capital flows into emerging markets. In addition, we can expect the unwinding of advanced economies' unconventional monetary expansion to have a tangible effect on financial stability in emerging markets as the capital flows reverse themselves; indeed, it is precisely such concerns about capital outflows that triggered turbulence in emerging financial markets when in May 2013, the US Federal Reserve Chairman Ben Bernanke merely signaled the intention to possibly start unwinding QE. The turbulence, known as taper tantrum, destabilized virtually all emerging financial markets and provoked fears of crises.

Prior to the global financial crisis and QE, there was relatively little research on the impact of the balance sheet policies of the central banks of advanced economies, perhaps due to their relatively limited scope. The body of research is even more limited for the spillover impact of such policies on emerging markets (Chen et al. 2012), but QE, which amounted to an unprecedented expansion of the US Federal Reserve balance sheet, has ignited interest in this line of research and has given rise to a growing body of literature on the impact and effectiveness of advanced economy central bank balance sheet policies (Chen, Mancini-Griffoli, and Sahay 2014). While those policies are geared toward domestic objectives such as safeguarding financial stability, supporting growth, or preventing deflation, they can nevertheless have significant spillover effects in other economies. In particular, the notion that $\mathrm{QE}$ and the unconventional monetary policies of other advanced economies along with the normalization of those policies can wreak havoc on emerging financial markets has almost become conventional wisdom.

The central objective of this paper is to assess this conventional wisdom more rigorously through econometric analysis. A limited but growing body of empirical literature has sprung up to assess the effect of the advanced economies' unconventional monetary policies and their unwinding on the financial stability of emerging markets. Eichengreen and Gupta (2014), for example, define 
financial instability as the sharp currency depreciations suffered by many emerging markets during the taper tantrum of May 2013 and try to identify the most important drivers of the depreciation. In addition to assessing the effect of QE on capital flows into emerging markets, Park, Ramayandi, and Shin (2014) perform a similar empirical exercise, also defining financial instability as exchange rate depreciation during the taper tantrum. In this paper, we instead define financial instability in emerging markets as a decline in their equity markets and examine the decline during the taper tantrum. In addition, we explore whether foreign exchange rate regimes affected the decline of emerging equity markets during the taper tantrum.

On a broader level, we hope that our study contributes to a better understanding of the effects of advanced economy unconventional monetary policies and their normalization on emerging markets. While financial shocks emanating from large advanced economies such as the US are likely to destabilize emerging markets, a more accurate analysis of their effects will help emerging market policy makers to better prepare to cope with such shocks. Section II reviews the existing literature on the effect of the taper tantrum on emerging markets. Section III describes the data used for the empirical analysis. Section IV lays out the empirical framework and reports and discusses the main findings. Section $\vee$ concludes the paper with overall observations, and puts forth some policy implications based on our empirical evidence.

\section{LITERATURE REVIEW}

There is a general agreement in the literature that emerging markets were significantly affected by the unconventional monetary policies of advanced economies. Recently, there have been a number of studies focusing on issues surrounding the taper talk in 2013 such as those by Aizenman, Banici, and Hutchinson (2014); Eichengreen and Gupta (2014); Mishra et al. (2014); Sahay et al. (2014); and Park, Ramayandi, and Shin (2014), among others. These studies used daily data on exchange rates and equity prices in addition to other high-frequency indicators to examine reactions in emerging markets

to the Federal Reserve announcement about possible tapering during the third period of the Federal Reserve's QE policy in late May 2013.

Using event analysis, Sahay et al. (2014) found that movements in asset prices and capital flows were strongly associated with announcements by the Federal Reserve. Their study indicates that initial announcements affected all economies indiscriminately, but over time the impact varied across economies depending on macroeconomic fundamentals. In particular, market reactions during the taper talk period were less evident in economies with stronger fundamentals, deeper financial markets, and better growth prospects. In another study, Chen, Mancini-Griffoli, and Sahay (2014) likewise employed event study techniques covering January 2000 to March 2014 and found that economies with stronger fundamentals were affected less by the US monetary policy shocks. Similarly, Mishra et al. (2014) analyzed market reactions to the US monetary policy using event analysis and underlined the importance of macroeconomic fundamentals in easing market pressures, particularly on exchange rates and government bond yields but not on stock markets. From these studies, the key message for emerging markets is the importance of economic fundamentals, policy credibility, and market liquidity in dampening impacts of advanced-economy monetary policies.

In contrast, Eichengreen and Gupta (2014) and Park, Ramayandi, and Shin (2014) found little evidence that economies with stronger macroeconomic fundamentals experienced smaller declines in exchange rates, foreign reserves, and stock prices. What they considered critical was the size of financial markets as economies with larger markets experienced more pressure on exchange rates, 
foreign reserves, and equity prices. Similar findings were also shown in Aizenman, Banici, and Hutchinson (2014).

As in other emerging markets, in developing Asia the announcement from the US Federal Reserve of a possible QE tapering pushed down stock prices, raised long-term bond yields and risk premiums, and weakened local currencies against the US dollar. The sharp depreciation of local currencies and declines in stock prices reflect reversals of earlier asset price increases and appreciations that emanated from large capital inflows. The stock market correction led markets to bottom out in the last week of June followed by an uneven recovery across economies. The financial market turmoil was felt most in India and Indonesia, economies that then experienced rising current account deficits with other macroeconomic imbalances even compounding India's vulnerability (ADB 2013).

An additional issue that other studies explore is the resilience of economies, depending on their exchange rate policies. It is not clear, however, whether domestic policies affecting exchange rates or external accounts helped stem spillovers. For example, Eichengreen and Gupta (2014) considered the extent by which real exchange rate appreciation from 2010 to 2012 was associated with more or fewer market reactions. They found that exchange rate regime had no separate significant impact on change in the equity price index or on change in reserves. In another study, Fratzscher, LoDuca, and Straub (2013) analyzed the global impact of the Federal Reserve's unconventional monetary policy during the first two periods of QE. While economies may have tried to shield themselves from the spillovers through, for example, interventions in foreign exchange markets or capital controls, Fratzscher, LoDuca, and R. Straub (2013) found no evidence that having a pegged exchange rate regime or a less open capital account helped economies to insulate themselves from the impact of QE. They further found that economies with stronger institutions and more active monetary policies were able to better withstand the shocks. Hence, they concluded that it is the use of monetary policy and not the maintenance of fixed exchange rate regimes that helps economies insulate themselves.

\section{DATA}

Our empirical investigation covers data on the equity markets of 22 developing economies, of which 9 are in developing Asia and 13 are outside the region. All economies experienced declines in equity price indices between the 22 May 2013 taper talk and the trough that occurred around the end of June of the same year.

Figure 1 shows that in developing Asia, economies with the largest declines in equity prices after the taper talk-the Philippines and Thailand-were among those that experienced the biggest boosts in their markets from the start of 2013 until the taper talk. In contrast, economies such as India and the Republic of Korea incurred lower declines in equity prices compared to their regional peers after the taper talk. For the Republic of Korea, macroprudential policies appeared to have worked well in insulating the economy against volatilities emanating from external shocks (Lee, Asuncion, and Kim 2015). In India, while strong policy measures have made the country's stock prices somewhat resilient, the impact of the QE announcement manifested itself on the local currency with the Indian rupee depreciating the most against the US dollar, reflecting the impact of macroeconomic balances (ADB 2013). In the case of Viet Nam, Figure 1 shows that stock prices were increasing prior to the taper talk and continued rising after that, although only mildly. However, if we compare the change in Viet Nam's equity prices from 22 May and 28 June, there was in fact a drop by about $4 \%$. 


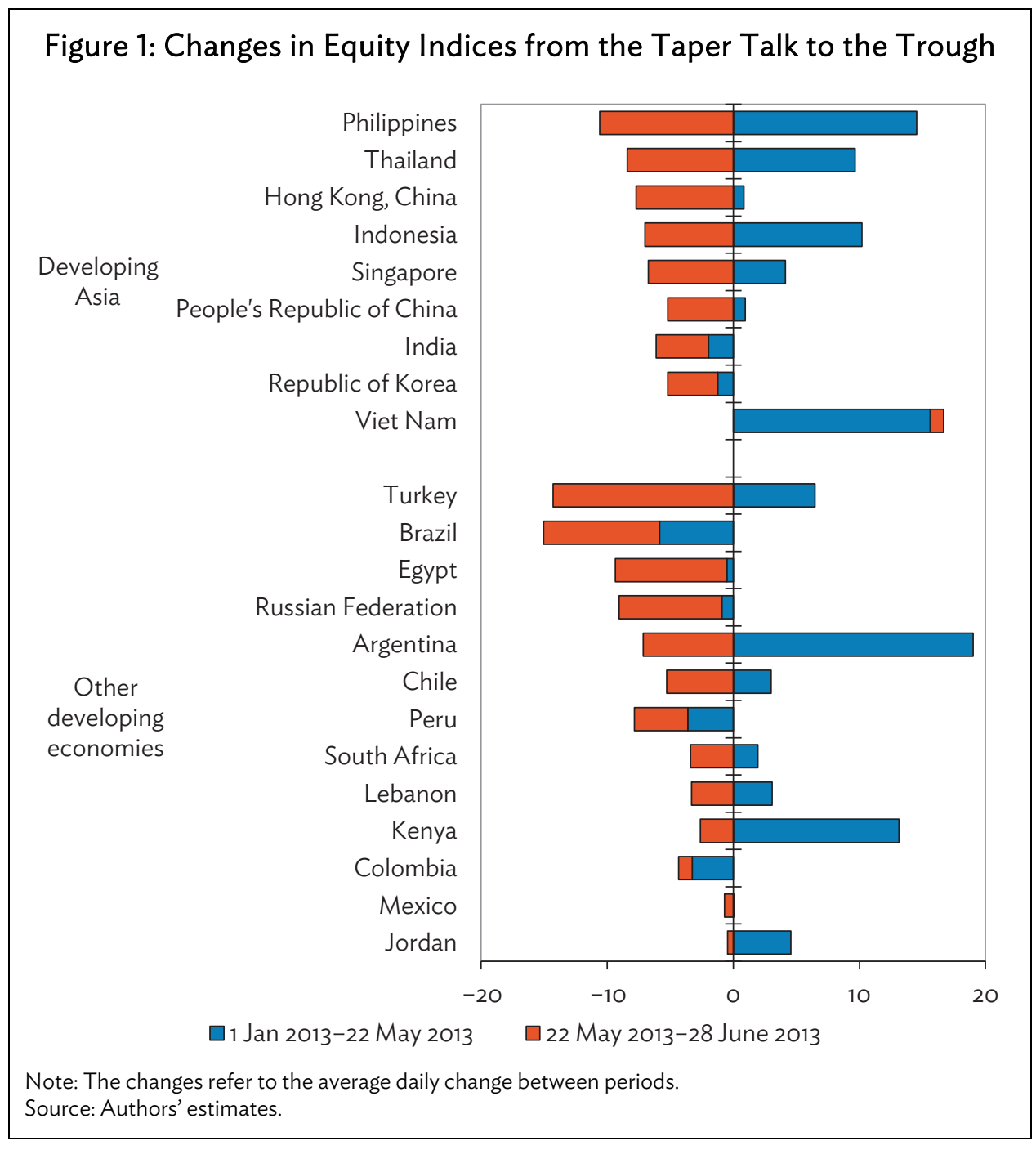

Outside Asia, a different picture emerges. Brazil, Egypt, and the Russian Federation were among those with the steepest drops in equity prices, but none of them experienced a rise in equity prices during the early part of the year. Thus, equity prices in these countries were already falling when the QE taper talk hit, which put further downward pressure on their equity markets. A similar pattern was evident in Colombia and Peru although the drop in their equity prices was not as steep as those of the other three economies outside Asia. Among Latin American countries, only Mexico registered a decline of less than $1 \%$ after the QE signal, but neither did it experience a stock market boom during the early part of the year.

We applied a country-level time series analysis to examine the impact of the Federal Reserve's announcement of its possible intention to taper its QE policy. We used daily data for 2013 on equity price indices as the dependent variable in the model and introduced a dummy variable to represent the period between the taper talk date and the trough at the end of June. We examined the autocorrelation function (ACF) and partial autocorrelation function of each economy series to determine the appropriate model (Figures 2 and 3). In general, we found that the ACF tended to decay over time while the partial autocorrelation function spiked at lag 1, which strongly suggests that all data series are characterized by an autoregressive model of order $1[A R(1)]$ process. 
Figure 2: Autocorrelation and Partial Autocorrelation Functions, Developing Asia

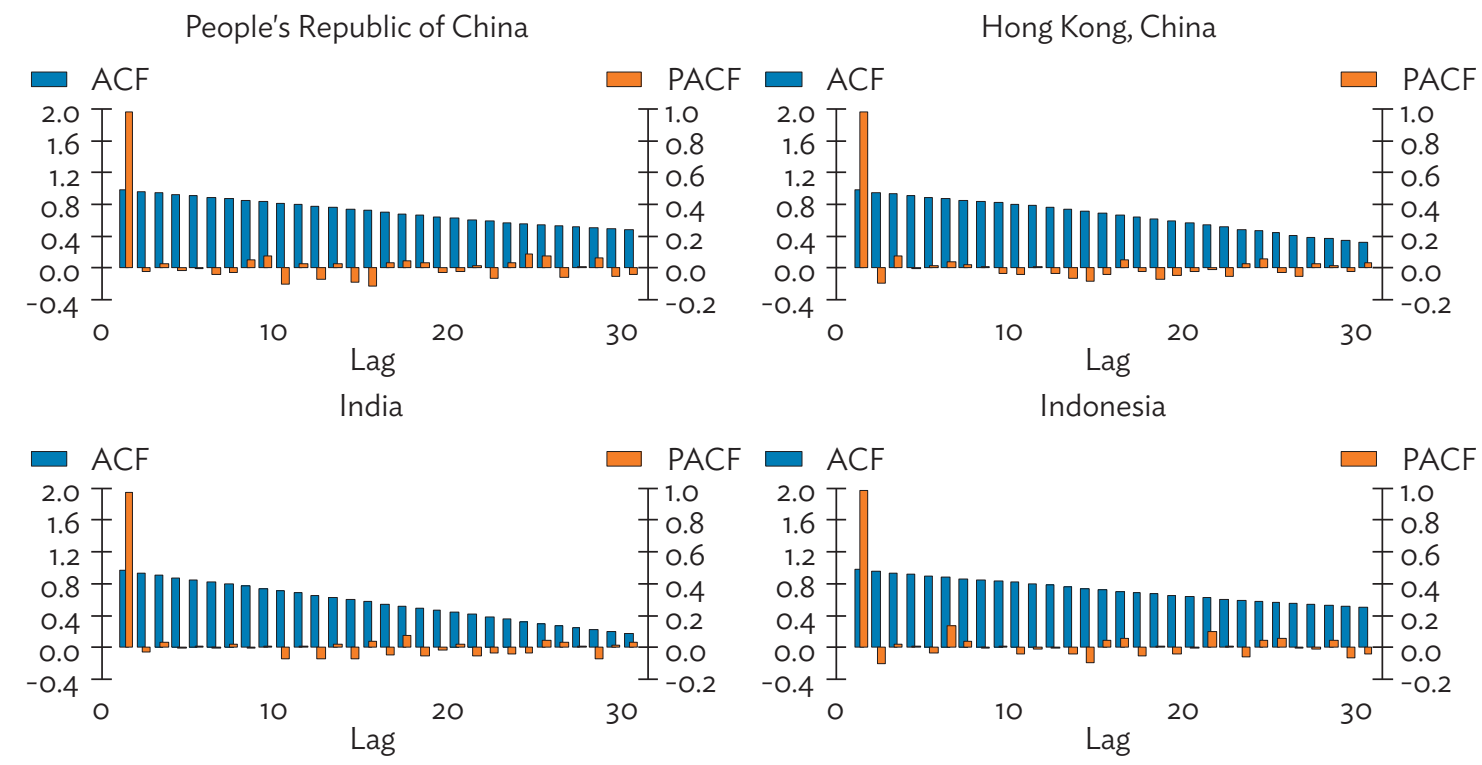

Republic of Korea

Philippines
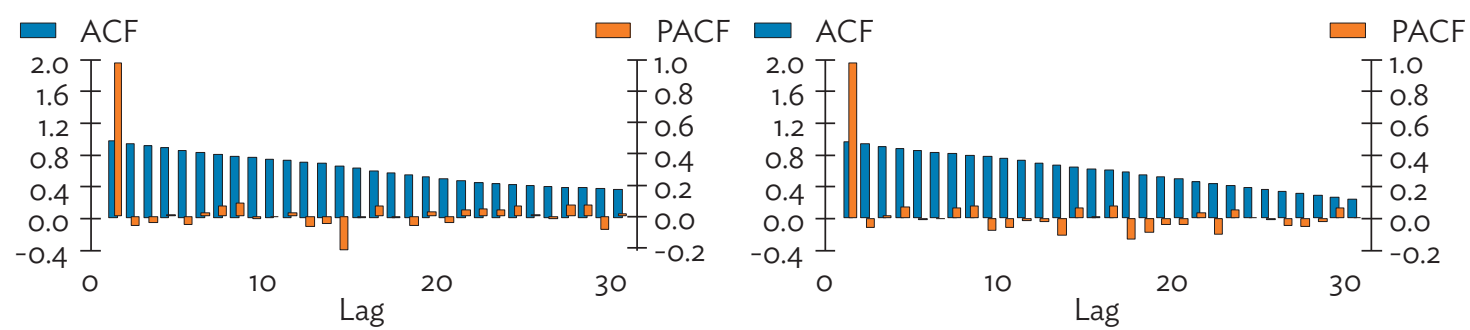

Singapore

Thailand

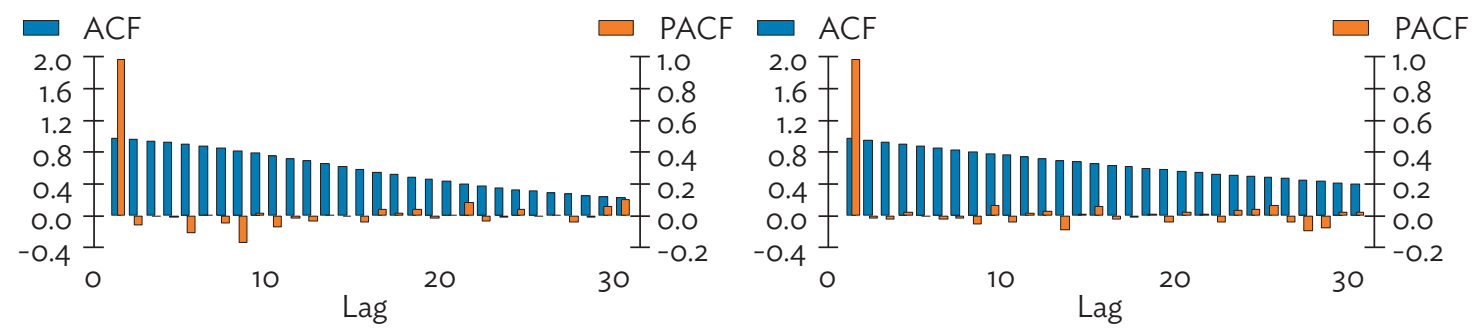

Viet Nam

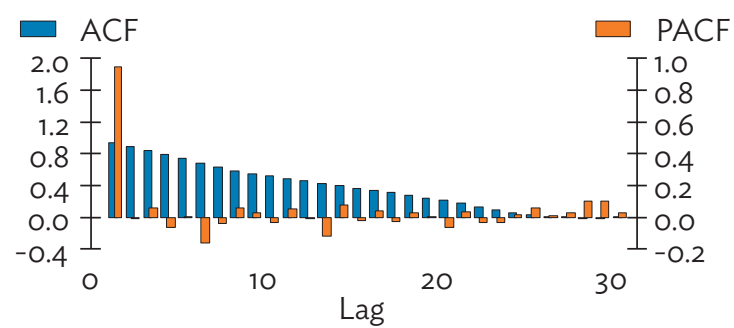

$\mathrm{ACF}=$ autocorrelation function, $\mathrm{PACF}=$ partial autocorrelation function. Source: Authors' estimates. 
Figure 3: Autocorrelation and Partial Autocorrelation Functions, Other Developing Economies
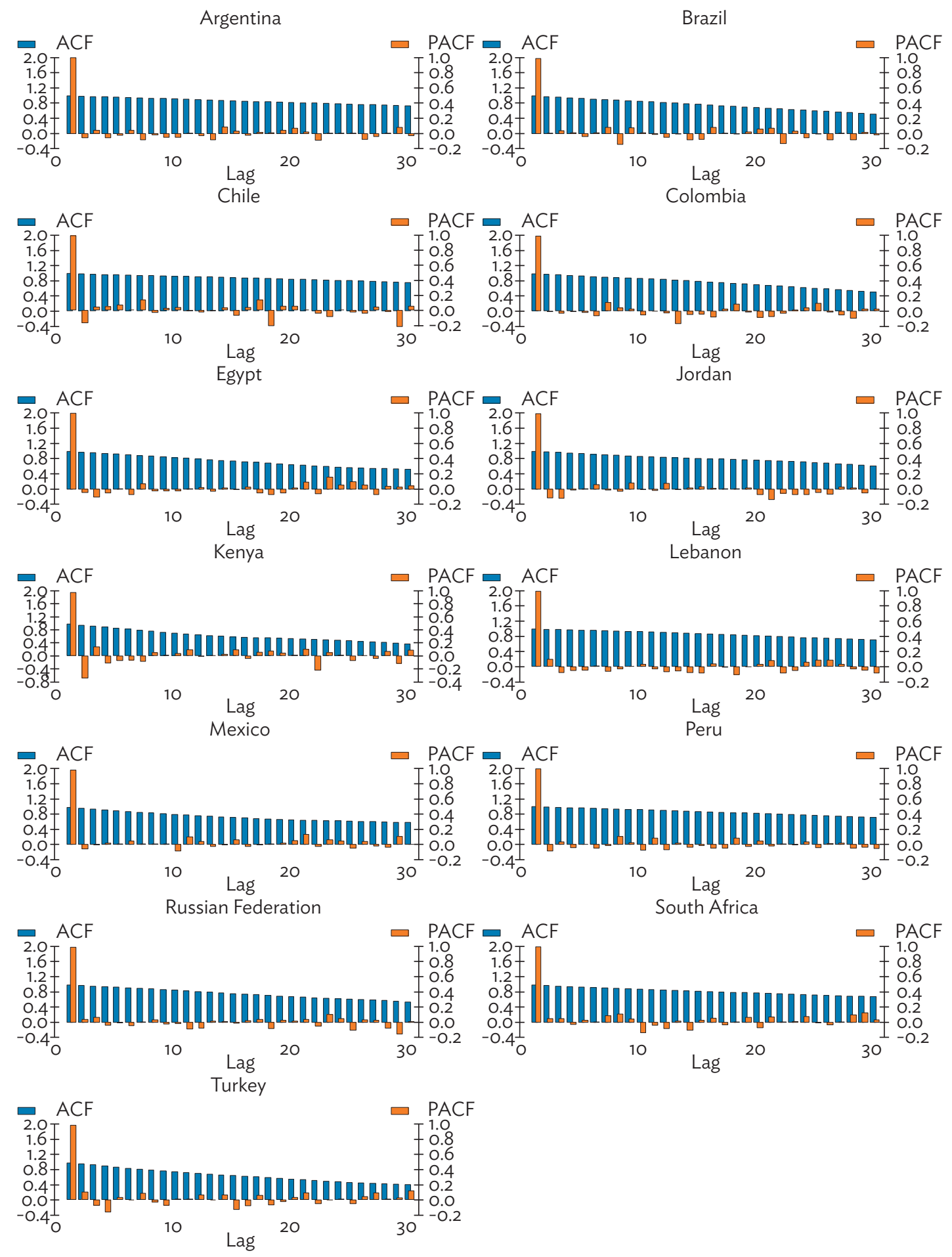

$\mathrm{ACF}=$ autocorrelation function, $\mathrm{PACF}=$ partial autocorrelation function Source: Authors' estimates. 


\section{EMPIRICAL ASSESSMENT}

\section{A. The Baseline Approach}

Following the characteristics of the sample data, our baseline approach is generalized as an $\operatorname{AR}(1)$ process augmented by a dummy variable that captures the taper tantrum episode as identified in the Asian Development Bank's Asian Development Outlook 2013 Update.

$$
\ln \left(E P_{t}\right)=\beta_{1}+\beta_{2} \ln \left(E P_{t-1}\right)+\beta_{3} d_{t}^{T T}+u_{t}
$$

$E P$ in Equation (1) represents the equity prices; $d^{T T}$ is the taper tantrum dummy that takes a value of 1 during the taper tantrum episode and 0 otherwise; $u$ is the random residual; and the subscript $t$ represents the period to which the variables are observed. $\beta_{1,2,3}$ are the relevant parameters.

Equation (1) is estimated using daily data on equity prices in 2013. Table 1 shows the results for each economy in our sample. As suggested by the ACF in Figures 2 and 3, equity prices in the emerging economies exhibit very persistent characteristics in all cases. This suggests that the daily movements of equity prices mostly follow the trend they encounter in the previous trading day and will be altered only if there were significant shocks to deflect the trends.

Equation (1) also tests the impact of the taper tantrum effect. The perceived signal that $\mathrm{QE}$ would end that caused havoc in financial markets around the globe invoked a continuous downturn in many emerging financial markets for about a month before the situation started to recover gradually. On page 14, the Asian Development Outlook 2013 Update notes that:

The 22 May "signal" triggered a global stock market correction. Markets bottomed out initially in the last week of June ("trough"), and the weeks that followed saw an uneven recovery as the statement was clarified.

Based on this note, the taper tantrum dummy $\left(d^{T T}\right)$ in our study is defined to take the value of 1 from 22 May to 28 June 2013 and 0 otherwise.

The results suggest that not all declines in the emerging equity markets were significantly affected by the taper tantrum (Column $4, \beta_{3}$ ); in Asia, they seem to have significantly affected the downturns only in the People's Republic of China; Hong Kong, China; the Republic of Korea; and Singapore. Despite the similar trend, the taper tantrum does not seem to have significantly induced the downturns in India, Indonesia, the Philippines, Thailand, and Viet Nam. The effect on equity prices outside Asia was also no less heterogeneous as they were significant in Argentina, Brazil, Egypt, Kenya, Lebanon, the Russian Federation, and South Africa, but not in the others in our sample.

Among those with significant results, the magnitude of the effects that the taper tantrum exerted on downturns in equity prices also varied among economies. Overall, Argentina seemed to be the most badly affected, but Hong Kong, China was the worst hit in developing Asia. The differences in both the significance and the magnitude of effects of the taper tantrum on equity price declines in emerging economies led to several interesting follow-up questions. Here, we explore two: (i) Does the way exchange rates are managed matter for the differences in the taper tantrum effect? and (ii) Did the taper tantrum really have no bearing on equity price declines in some emerging markets? 
Table 1: Estimation Results of Equation (1)

\begin{tabular}{|c|c|c|c|c|}
\hline Economy & $\beta_{1}$ & $\beta_{2}$ & $\beta_{3}$ & $\begin{array}{c}\text { Durbin- } \\
\text { Watson Stat }\end{array}$ \\
\hline \multicolumn{5}{|l|}{ Developing Asia } \\
\hline PRC & $0.130^{*}$ & $0.983^{* * *}$ & $-0.004^{* * *}$ & 1.998 \\
\hline Hong Kong, China & $0.372^{* * *}$ & $0.963^{* * *}$ & $-0.005^{* * *}$ & 1.859 \\
\hline India & $0.210^{* *}$ & $0.976^{* * *}$ & -0.002 & 1.947 \\
\hline Indonesia & 0.112 & $0.987^{* * *}$ & -0.001 & 1.790 \\
\hline Republic of Korea & $0.230^{* *}$ & $0.970^{* * *}$ & $-0.003^{* *}$ & 1.908 \\
\hline Philippines & $0.176^{*}$ & $0.980^{* * *}$ & -0.003 & 1.901 \\
\hline Singapore & 0.128 & $0.984^{* * *}$ & $-0.003^{* * *}$ & 1.929 \\
\hline Thailand & 0.075 & $0.990^{* * *}$ & -0.003 & 1.980 \\
\hline Viet Nam & $0.333^{* * *}$ & $0.946^{* * *}$ & 0.000 & 1.979 \\
\hline \multicolumn{5}{|c|}{ Other Developing Economies } \\
\hline Argentina & 0.056 & $0.994^{* * *}$ & $-0.009^{* * *}$ & 1.938 \\
\hline Brazil & $0.190^{* *}$ & $0.983^{* * *}$ & $-0.005^{* * *}$ & 2.031 \\
\hline Chile & 0.030 & $0.996^{* * *}$ & -0.001 & 1.678 \\
\hline Colombia & $0.115^{*}$ & $0.988^{* * *}$ & -0.001 & 1.985 \\
\hline Egypt & 0.088 & $0.990^{* * *}$ & $-0.006^{* * *}$ & 1.944 \\
\hline Jordan & 0.056 & $0.993^{* * *}$ & -0.001 & 1.763 \\
\hline Kenya & $0.171^{* * *}$ & $0.980^{* * *}$ & $-0.002^{* *}$ & 1.343 \\
\hline Lebanon & 0.034 & $0.995^{* * *}$ & $-0.002^{* * *}$ & 2.262 \\
\hline Mexico & $0.250^{* *}$ & $0.977^{* * *}$ & -0.001 & 1.870 \\
\hline Peru & 0.056 & $0.994^{* * *}$ & -0.002 & 1.825 \\
\hline Russian Federation & $0.222^{* * *}$ & $0.969^{* * *}$ & $-0.005^{* * *}$ & 2.095 \\
\hline South Africa & 0.110 & $0.990^{* * *}$ & $-0.002^{*}$ & 2.103 \\
\hline Turkey & 0.155 & $0.986^{* * *}$ & -0.004 & 2.232 \\
\hline
\end{tabular}

PRC = People's Republic of China.

Notes: ${ }^{* *} p<0.01,{ }^{* *} p<0.05,{ }^{*} p<0.1 . \beta_{1}$ represents the constant, $\beta_{2}$ is the coefficient of lagged equity price index, and $\beta_{3}$ is the coefficient of the taper tantrum dummy variable.

Source: Authors' estimates.

\section{B. Does the Exchange Rate Regime Matter?}

For the purpose of our analysis, we used the International Monetary Fund (IMF) 2013 definition of exchange rate regimes and reclassified them into two categories: flexible exchange rate regimes and managed exchange rate regimes. The IMF definition refers to the de facto classification as of April 2013 in the Annual Report on Exchange Arrangements and Exchange Restrictions. In this classification, managed regimes include all the controlled type of exchange rate regimes under the IMF definition ranging from the fixed exchange rate regime to the managed floating regime. Table 2 shows the exchange rate regimes adopted by the emerging economies in our sample. 
Table 2: Exchange Rate Regime Classifications

\begin{tabular}{lccc}
\hline Developing Asia & ER Regime & Nondeveloping Asia & ER Regime \\
\hline PRC & Managed & Argentina & Managed \\
Hong Kong, China & Managed & Brazil & Flexible \\
India & Flexible & Chile & Flexible \\
Indonesia & Managed & Colombia & Flexible \\
Republic of Korea & Flexible & Mexico & Flexible \\
Philippines & Flexible & Peru & Flexible \\
Singapore & Managed & Turkey & Flexible \\
Thailand & Flexible & Russian Federation & Managed \\
Viet Nam & Managed & South Africa & Flexible \\
& & Kenya & Flexible \\
& & Egypt & Managed \\
& & Lebanon & Managed \\
& & Jordan & Managed \\
\hline
\end{tabular}

ER $=$ exchange rate, $P R C=$ People's Republic of China.

Source: Authors' classification based on IMF (2013).

The magnitude of $\beta_{3}$ in Table 1 and the classification of exchange rate regimes in Table 2 reveal some patterns about how exchange rate regimes might be related to the severity of the taper tantrum effect on equity prices in emerging economies. Regrouping our sample into the two classifications of exchange rate regimes and computing the average magnitude of $\beta_{3}$ for each group suggest that the degree of severity of the fall in equity prices during the taper tantrum $\left(\beta_{3}\right)$ was worse in economies with managed exchange rate regimes than in those with flexible regimes. The difference is obvious when we consider only those with statistically significant coefficients (as we should), where the average severity of the taper tantrum impact in economies with flexible exchange rate regimes is only about $67 \%$ of that in economies with managed regimes $(-0.32 \%$ versus $-0.48 \%$, respectively).

When the sample is broken down into emerging economies in Asia and elsewhere, the differences in terms of taper tantrum effect on equity prices remain. Although the ratio of the average severity of the taper tantrum impact does not change substantially, the average magnitude of $\beta_{3}$ varies quite substantially between emerging economies in Asia and elsewhere. The average fall in equity prices during the taper tantrum in emerging Asia was $-0.41 \%$ in economies with managed exchange rate regimes and $-0.25 \%$ in those with flexible regimes. In emerging economies elsewhere, the drop in equity prices was $-0.53 \%$ in those with managed regimes and $-0.34 \%$ in those with flexible regimes.

These observations suggest that equity markets in emerging Asia tended to be more resilient than elsewhere during the taper tantrum. In addition, the evidence also suggests that equity markets are more resilient under a flexible exchange rate regime than under a managed one. This is consistent with the classic Friedman hypothesis (Friedman 1953) that suggests the benefits of a flexible exchange rate regime to more effectively insulate an economy against external real shocks as demonstrated in, for example, Broda (2004), and Edwards and Levi Yeyati (2005). Our finding goes even further by suggesting that a flexible exchange rate regime can also act as an automatic filter to volatile capital flow reversals resulting from news shocks from the external environment.

The averages, however, are masking individual variations in the severity of the taper tantrum effects. The magnitude of $\beta_{3}$ for those with managed exchange rate regimes ranged from $-0.2 \%$ in the 
case of Lebanon to $-0.9 \%$ in the case of Argentina. For those with flexible regimes, the range is from $0.2 \%$ in the case of Kenya and South Africa to $-0.5 \%$ in Brazil.

Ghosh, Quresshi, and Charalambos (2013) argue that the official exchange rate regimes may not be an appropriate reflection of the actual exchange rate flexibility of an economy. Despite a peg to the US dollar, for example, an economy's exchange rate may actually be fluctuating against its important trading partners' currencies. That said, the economy's currency may actually be volatile in terms of its real effective exchange rate despite the peg to the US dollar. In this regard, we also used trade-weighted bilateral exchange rate volatility to look for additional explanations of the varying degrees of the severity of the impact of the taper tantrum on emerging economy equity markets.

We used real effective exchange rate (REER) data from the Bank for International Settlements (BIS) to measure trade-weighted bilateral exchange rates. The standard deviation of monthly REERs for 2013 was computed to capture their volatility and to classify an economy as "less volatile" if its standard deviation was lower than the average REER volatility of our sample with REER data or to label it as "more volatile" otherwise. Of the 22 economies in our sample, only 17 are included in the BIS REER dataset: REER data for Egypt, Jordan, Kenya, Lebanon, and Viet Nam were not available.

Table 3 shows the REER volatility classification for economies with direct, significant effects from the taper tantrum on equity prices along with other information relevant for our analysis. It shows that economies with more volatile REERs tended to suffer greater impacts from the taper tantrum according to the exchange rate regime adopted. Argentina, which happens to have a combination of a managed exchange rate regime and a more volatile REER, is shown to have suffered the worst impact from the taper tantrum.

\section{Table 3: Relative Real Effective Exchange Rate Volatility against the Sample Average}

\begin{tabular}{lccc}
\hline Economy & $\boldsymbol{\beta}_{\mathbf{3}}$ & $\begin{array}{c}\text { Exchange Rate } \\
\text { Regime }\end{array}$ & REER Volatility \\
\hline Hong Kong, China & -0.005 & Managed & Less volatile \\
PRC & -0.004 & Managed & Less volatile \\
Singapore & -0.003 & Managed & Less volatile \\
Argentina & -0.009 & Managed & More volatile \\
Russian Federation & -0.005 & Managed & Less volatile \\
Republic of Korea & -0.003 & Flexible & Less volatile \\
Brazil & -0.005 & Flexible & More volatile \\
South Africa & -0.002 & Flexible & More volatile \\
\hline
\end{tabular}

$\mathrm{PRC}=$ People's Republic of China, REER = real effective exchange rate. Note: $\beta_{3}$ is the coefficient of the taper tantrum dummy in Equation (1). Source: Authors' calculations and classification.

\section{Indirect Channel of the Taper Tantrum Effect}

The previous discussion leaves a question about what drove an equity price slump in economies in which the direct effect of taper tantrum was statistically insignificant. Were they really unaffected, and was the decline in their equity prices a result of purely idiosyncratic shocks that applied only to their specific individual economies? To shed light on these questions, we tested for possible regional effects through regional financial hubs for these economies. We limited the test to the emerging Asia sample as it includes two influential hubs: Singapore and Hong Kong, China. 


$$
\ln \left(E P_{t}\right)=\beta_{1}+\beta_{2} \ln \left(E P_{t-1}\right)+\beta_{3} d_{t}^{T T}+\beta_{4}\left(E P_{t}^{H K}\right)+\beta_{5}\left(E P_{t}^{S G}\right)+v_{t}
$$

Equation (2) is an augmented version of Equation (1) that includes two additional components ( $E P_{t}^{H K}$ and $E P_{t}^{S G}$ ) to capture the contemporaneous effects of changes in the equity prices of the regional hubs: Singapore and Hong Kong, China, respectively.

Table 4 shows that there were significant, contemporaneous effects from the regional financial hubs to the emerging Asian economies with statistically insignificant $\beta_{3}$ values in Equation (1). While the degree of severity of the fall in equity prices during the taper tantrum $\left(\beta_{3}\right)$ remains largely insignificant, movements of equity prices in Hong Kong, China were contemporaneously affecting prices in India and Viet Nam positively. This implies that the taper tantrum was actually affecting the two economies indirectly through their effect on Hong Kong, China. The other three Southeast Asian countries (Indonesia, the Philippines, and Thailand) were also exposed to an indirect taper tantrum effect through equity price changes in Singapore. Therefore, none of the Asian emerging equity markets in our sample was spared by the taper tantrum. All of them were either hit directly or indirectly through regional contagion.

Table 4: Estimation Results of Equation (2)

\begin{tabular}{lccccc}
\hline Economy & $\boldsymbol{\beta}_{\mathbf{1}}$ & $\boldsymbol{\beta}_{\mathbf{2}}$ & $\boldsymbol{\beta}_{\mathbf{3}}$ & $\boldsymbol{\beta}_{\mathbf{4}}$ & $\boldsymbol{\beta}_{\mathbf{5}}$ \\
\hline India & 0.054 & 0.955 & 0.000 & 0.038 & -0.006 \\
p-value & 0.764 & 0.000 & 0.989 & 0.029 & 0.729 \\
\hline Indonesia & -0.659 & 0.846 & 0.004 & -0.063 & 0.320 \\
p-value & 0.002 & 0.000 & 0.092 & 0.003 & 0.000 \\
\hline Philippines & -0.603 & 0.857 & -0.003 & -0.048 & 0.290 \\
p-value & 0.006 & 0.000 & 0.197 & 0.012 & 0.000 \\
\hline Thailand & -0.988 & 0.876 & -0.001 & -0.012 & 0.250 \\
p-value & 0.000 & 0.000 & 0.702 & 0.454 & 0.000 \\
\hline Viet Nam & -0.185 & 0.946 & 0.002 & 0.032 & 0.024 \\
p-value & 0.343 & 0.000 & 0.226 & 0.014 & 0.146 \\
\hline
\end{tabular}

Notes: $\beta_{1}$ represents the constant; $\beta_{2}$ is the lagged equity price index; $\beta_{3}$ is the taper tantrum dummy; $\beta_{4}$ is the effect of Hong Kong, China; and $\beta_{5}$ is the effect of Singapore.

Source: Authors' estimates.

\section{CONCLUSION}

In a desperate attempt to stave off financial meltdowns and to support growth in the face of collapsing demand during the global financial crisis, the central banks of the advanced economies embarked upon an unprecedented, unconventional monetary expansion-an extraordinary policy response to an extraordinary shock. In particular, the US Federal Reserve's massive purchases of US government bonds, known as QE, led to a huge expansion of its balance sheet. In the case of Japan, fending off deflation and generating inflation was a major driver of the Bank of Japan's monetary stimulus under "Abenomics." While the unconventional monetary policies of the advanced economies were motivated by domestic policy objectives, those policies and their unwinding can have significant spillover effects on other economies. According to conventional wisdom, capital flows and capital flow 
reversals due to such policy actions have had a major destabilizing effect on emerging markets, which tend to rely heavily on capital flows from advanced economies and are financially less developed.

In this paper, we empirically examined this conventional wisdom by investigating the effect of the taper tantrum triggered by the US Federal Reserve Chairman Ben Bernanke's announcement of a possible intent to unwind QE in May 2013 on the equity markets of emerging economies. A number of interesting and significant findings emerged. Daily movements of equity prices in emerging markets are mostly persistent; the daily trends will be altered only if there are large shocks. Not all declines in emerging equity market prices during the taper tantrum were direct effects of them. The taper tantrum dummy had a statistically significant effect on equity price declines in only some of the economies in our sample. Furthermore, emerging equity markets in Asia were more resilient than emerging markets elsewhere during the taper tantrum, perhaps due to their strong fundamentals. Equity markets were also more resilient under flexible exchange rate regimes than under managed regimes. Within each exchange rate regime, economies with more volatile REERs tended to be more vulnerable.

Notwithstanding the apparent absence of a direct effect in some economies, none of the Asian emerging equity markets in our sample was immune to the destabilizing effects of the taper tantrum because even those that were not affected were indirectly affected through regional contagion. The indirect effects coming through the region's financial hubs highlight the role of regional financial market interconnectedness in transmitting external shocks. On a narrow level, our evidence lends some support to the notion that more flexible exchange regimes mitigate vulnerability to external financial shocks. Since REER volatility is often due to macroeconomic instability, e.g. high and volatile inflation, our evidence suggests that macroeconomic stability can also help. On a broader level, our evidence reconfirms the conventional wisdom that unconventional monetary policies of advanced economy central banks and their unwinding have had significant effects on the financial stability of emerging markets underlining the need for emerging market authorities to remain vigilant. 


\section{REFERENCES}

Aizenman, J., M. Banici, and M. M. Hutchinson. 2014. Transmission of Federal Reserve Tapering to Emerging Financial Markets. NBER Working Paper Series No. 19980. Cambridge, MA: National Bureau of Economic Research.

Asian Development Bank (ADB). 2013. Time for Vigilance and Reform. In Asian Development Outlook 2013 Update. Manila.

Bank for International Settlements (BIS). BIS Effective Exchange Rate Indices. http://www.bis.org/ statistics/index.htm

Broda, C. 2004. Terms of Trade and Exchange Rate Regimes in Developing Countries. Journal of International Economics. 63 (1). pp. 31-58.

Chen, Q., A .Filardo, D. He, and F. Zhu. 2012. International Spillovers of Central Bank Balance Sheet Policies. BIS Working Paper No. 66. Basel: Bank for International Settlements.

Chen, J., T. Mancini-Griffoli, and R. Sahay. 2014. Spillovers from United States Monetary Policy on Emerging Markets: Different This Time? IMF Working Paper No. WP/14/240. Washington, DC: International Monetary Fund.

Edwards, S. and E. Levy Yeyati. 2005. Flexible Exchange Rates as Shock Absorbers. European Economic Review. 49 (8). pp. 2079-2105.

Eichengreen, B. and P. Gupta. 2014. Tapering Talk: The Impact of Expectations of Reduced Federal Reserve Security Purchases on Emerging Markets. Munich Personal RePEc Archive Paper No. 53040. Munich: University of Munich, University Library.

Fratzscher, M., M. LoDuca, and R. Straub. 2013. A Global Monetary Tsunami: On the Spillovers of US Quantitative Easing. CEPR Discussion Paper No. 9195. Washington, DC: Center for Economic and Policy Research.

Friedman, M. 1953. The Case for Flexible Exchange Rates. In Essays in Positive Economics. Chiago: University of Chicago Press.

Ghosh, A.R., M. S. Quresshi, and C. G. Charalambos. 2013. Is the Exchange Rate Regime Really Irrelevant for External Adjustment? Economics Letters. 118 (1). pp. 104-9.

International Monetary Fund (IMF). 2013. Annual Report on Exchange Arrangements and Exchange Restrictions. Washington, DC.

Lee, M., C. R. Asuncion, and J. Kim. 2015. Effectiveness of Macroprudential Policies in Developing Asia: an Empirical Analysis. ADB Economics Working Paper Series No. 439. Manila: Asian Development Bank.

Mishra, P., K. Moriyama, P. N'Diaye, and L. Nguyen. 2014. Impact of Fed Tapering Announcements on Emerging Markets. IMF Working Paper No. WP/14/109. Washington, DC: International Monetary Fund. 
Park, D., A. Ramayandi, and K. Shin. 2014. Capital Flows during Quantitative Easing and Aftermath: Experiences of Asian Countries. ADB Economics Working Paper Series No. 409. Manila: Asian Development Bank.

Sahay, R., V. Arora, T. Arvanitis, H. Faruqee, P. N'Diaye, T. Mancini-Griffoli, and an IMF Team. 2014. Emerging Market Volatility: Lessons from the Taper Tantrum. IMF Staff Discussion Note No. SDN/14/09. Washington, DC: International Monetary Fund. 


\section{Taper Tantrum and Emerging Equity Market Slumps}

This paper empirically examines the effect of the taper tantrum on the equity markets of emerging economies. The study finds that virtually all emerging market equity markets were affected by the taper tantrum, thus highlighting the need for emerging market authorities to remain vigilant about the effects of advanced economy monetary policies on their financial stability.

\section{About the Asian Development Bank}

ADB's vision is an Asia and Pacific region free of poverty. Its mission is to help its developing member countries reduce poverty and improve the quality of life of their people. Despite the region's many successes, it remains home to the majority of the world's poor. $A D B$ is committed to reducing poverty through inclusive economic growth, environmentally sustainable growth, and regional integration.

Based in Manila, ADB is owned by 67 members, including 48 from the region. Its main instruments for helping its developing member countries are policy dialogue, loans, equity investments, guarantees, grants, and technical assistance. 